\title{
DOŚWIADCZENIA KULTUROWE SPOŁECZEŃSTWA UTRWALONE W ZWIĄZKACH FRAZEOLOGICZNYCH - ASPEKT PEDAGOGICZNY
}

\begin{abstract}
Kuszak Kinga, Doświadczenia kulturowe spoteczeństwa utrwalone w zwiazkach frazeologicznych - aspekt pedagogiczny [Society's Cultural Experience as Preserved in Phrasemes - the Pedagogical Aspect]. Studia Edukacyjne nr 41, 2016, Poznań 2016, pp. 37-53. Adam Mickiewicz University Press. ISSN 1233-6688. DOI: $10.14746 /$ se.2016.41.3
\end{abstract}

The article discusses the cultural experience preserved in language in the form of more or less popular phrasemes. The author identifies selected sources of the phrasemes and depicts their function in preserving and saving the cultural heritage of past generations. She highlights the changes taking place in the contemporary language. The author underlines the multidirectional nature of these changes: on the one hand, society preserves the linguistic heritage, while on the other hand it gives new meanings to previously known words and sayings, creates new words and phrasemes which allow a reflection on the current socio-cultural experiences of individuals and social groups. The summary indicates the educational aspect of the issue and the necessity of implementing a carefully planned native language education which will support developing the identities of individuals, social groups and society as a whole.

Key words: culture, language, language education, phrasemes

\section{Wprowadzenie}

W naukach społecznych pod pojęciem kultury ujmuje się to wszystko, co jest przekazywane jednostkom i grupom społecznym w procesie enkulturacji (akulturacji). Proces transmisji kulturowej, inaczej - wrastania w kulturę, dokonuje się w trzech „układach” wyróżnionych przez Antoninę Kłoskowską. Pierwszy, nazwany przez autorkę pierwotnym, dotyczy małych społeczności i charakteryzuje się bliskością psychofizyczną członków grupy, 
podobieństwem ich życiowych losów i doświadczeń. Drugi układ - instytucjonalny, podobnie jak poprzedni, oparty jest na kontaktach bezpośrednich, przy jednoczesnym występowaniu kontaktów formalnych pomiędzy ludźmi, którzy pełnią względem siebie określone role, np. nauczyciel-uczeń, widz-aktor. Funkcja nadawcy przekazu kulturowego ma charakter formalny i określa jego rolę społeczną. Natomiast, funkcja odbiorcy nie jest trwała, gdyż człowiek tylko przejściowo jest uczniem, widzem itp. Trzeci układ kultury opiera się na środkach pośredniego komunikowania między nadawcą a odbiorcą i dotyczy treści przekazywanych za pośrednictwem mass mediów. Kultura współczesnych rozwiniętych społeczeństw obejmuje elementy wszystkich trzech układów, które są wzajemnie powiązane i zazębiają się ze sobą ${ }^{1}$. Każda jednostka funkcjonuje $\mathrm{w}$ trzech wymienionych układach, a proces jej wrastania w kulturę dokonuje się stopniowo i towarzyszy jej biologicznemu rozwojowi. Ważną rolę $\mathrm{w}$ tym procesie odgrywa język. Z jednej strony jest on przekazywany kolejnym pokoleniom w procesie socjalizacji (elementem socjalizacji jest nabywanie języka, umiejętności porozumiewania się, reagowania na określone typy komunikatów itp.), z drugiej strony stanowi narzędzie przekazywania znaczeń i wyrażania kultury, gdyż „język może przenikać wszystkie sfery działalności kulturalnej”2 E. Sapir zauważa, że

zawartość treściowa każdej kultury daje się wyrazić w jej języku i nie ma takiego materiału językowego (...), który by dla użytkowników danego języka nie symbolizował rzeczywistych znaczeń3.

W tym znaczeniu język stanowi „przekaźnik” szerszej kultury oraz obrazuje doświadczenia jej uczestników. Również J. Anusiewicz, A. Dąbrowska, M. Fleischer traktują język jako swoiste medium dorobku kulturowego wspólnoty komunikacyjnej. Zdaniem tych autorów, język jest wyrazem praktyki społecznej tej wspólnoty oraz jej doświadczeń nagromadzonych w ciągu wielu pokoleń. Za jego pośrednictwem możliwe jest przekazywanie wartości, ocen i wartościowań oraz norm postępowania, wokół których koncentrują się zachowania, działania, przekonania oraz system etycznonormatywny danej społecznościł. Według M. Fleischera, język „odzwiercie-

${ }^{1}$ M. Filipiak, Obszar badawczy socjologii kultury, [w:] Wprowadzenie do socjologii kultury, red. M. Filipiak, Lublin 2009, s. 60-61.

2 A. Kłoskowska, Socjologia kultury, Warszawa 2007, s. 101.

${ }^{3}$ E. Sapir, Kultura a osobowość, Warszawa 1987, s. 37-38.

4 J. Anusiewicz, A. Dąbrowska, M. Fleischer, Językowy obraz świata i kultura. Projekt koncepcji badawczej, [w:] Jezzyk a kultura, t. 13, Wrocław 2000, s. 21. 
dla społeczną rzeczywistość oraz wartości kulturowe i tworzy formę społecznych zachowań"5. Można więc powiedzieć, że poszczególne elementy języka, jak: gramatyka, słownictwo, frazeologia, składnia, struktura tekstu, semantyka, etymologia, stylistyka są swoistym odzwierciedleniem kulturowego doświadczenia jednostek i zbiorowości.

\section{Doświadczenie kulturowe zapisane w związkach frazeologicznych}

Język jest swoistym systemem znaków, zaś znaki językowe są arbitralne, tzn.

nie ma powodu, który usprawiedliwiałby przyporządkowanie takiego, czy innego sygnału do danego znaczenia. To właśnie dlatego w różnych językach to samo znaczenie kodowane jest za pomocą odmiennych sygnałów ${ }^{6}$.

Znaczenie „kon" związane jest w języku polskim z formą dźwiękową koń, w języku francuskim cheval, w angielskim horse, niemieckim Pferd, zaś włoskim cavallo. Każdy z tych wyrazów zawiera określoną treść (sens, znaczenie), jednakże ściśle określony „sens jawi się wyłącznie dla umysłu i w umyśle i właściwie z niego nie wychodzi"7. Warto też zaznaczyć, że sens, który chcemy wyrazić $\mathrm{w}$ języku zmienia się w zależności od postępu naukowego i cywilizacyjnego społeczeństwa. Zmienia się również sam język, za pomocą którego ten sens chcemy wyrazić i przekazać innym ludziom $\mathrm{w}$ procesie komunikacji społecznej. Przybywają nowe słowa, za pomocą których kolejne pokolenia określają na przykład przedmioty codziennego użytku (np. komputer, smartfon, tablet), zjawiska społeczne (np. eurosieroctwo), czynności (np. lajkować, hejtowac), zawody i aktywności ludzi (np. bloger, youtuber, szafiarka). Próbę zdefiniowania czym zajmuje się współczesna szafiarka podjął m.in. Andrzej Markowski, ujmując to w następujący sposób:

szafiarka-to osoba-zwykle dziewczyna, młoda, która prowadzi blog poświęcony modzie i w tym blogu lansuje różne kreacje wymyślone przez siebie i na sobie sprawdzone, czyli w które się odziewa i pokazuje to na zdjęciach z blogu. Kreacje

\footnotetext{
${ }^{5}$ M. Fleischer, Obraz świata. Ujęcie z punktu widzenia teorii systemów i konstruktywizmu, Acta Universites Wratislaviensis, t. 13, Wrocław 2000, s. 47.

${ }^{6}$ Ch. Baylon, X. Mignot, Komunikacja, Kraków 2008, s. 24.

7 Tamże, s. 26.
} 
muszą być oryginalne, zwariowane i złożone z elementów nienowych. Bo szafiarka często zagląda do ciucheksów, szmateksów, lumpeksów czy też innych second-handów8.

Przytoczony przykład stanowi próbę wyrażenia za pomocą środków językowych pewnego zjawiska socjologicznego.

Analizy językoznawcze pozwalają dostrzec, że pewne słowa wychodzą z obiegu, gdyż z użycia wychodzą np. przedmioty określane przez te słowa, np. kałamarz, stalówka, patarafka ${ }^{9}$, farfura10, imbryk, bibuła. Zmienia się garderoba, co powoduje zanikanie we współczesnym języku takich słów, jak np. tiurniura, żabot, kaftan, cylinder, melonik, sak, pumpy, szarawary, tużurek ${ }^{11}$, podobnie rzecz ma się z uczesaniem. Najmłodsze pokolenie użytkowników języka z pewnością nie wie czym jest plereza. Zanikają pewne potrawy, jak np. legumina. Znikają też zawody, np. stenotypistka, praczka, dojarka12, fiakier, kamerdyner, zatem z powszechnego użycia wychodzą słowa je określające. Najmłodsze pokolenie z pewnością nie wie, kim był roznosiciel mleka, gdyż zawód ten nie jest już wykonywany. Podobnie nie istnieje już zawód repasarki - osoby, która w latach 70-80. XX wieku zajmowała się naprawianiem (repasacją) podartych pończoch i rajstop. Niektóre znaczenia wyrażane są we współczesnym języku za pomocą nowych słów, jak choćby słowo kajet zastąpione zostało słowem zeszyt, a słowo suty, wyparte zostało przez słowo obfity. Pewne słowa zyskują też nowe znaczenia i np. herbatniki - obecnie popularne ciasteczka (podawane niekoniecznie do herbaty), kiedyś herbatnik oznaczał amatora herbaty, obecnie zwanego herbaciarzem ${ }^{13}$. Z kolei słowo moher, które w Słowniku języka polskiego definiowane jest jako „wełna kóz angorskich; przędza, lekka tkanina z wełny"14, współcześnie używane jest jako obraźliwe określenie osoby w podeszłym wieku. Słowo to funkcjonuje w potocznej polszczyźnie w formie związku frazeologicznego moherowy beret i wyraża "lekceważące określenie starszych, wierzących ludzi, przywiązanych do tradycyjnych, katolickich i konserwatywnych wartości"15.

8 J. Bralczyk, A. Markowski, J. Miodek, Trzy po 33, Warszawa 2016, s. 104.

9 "Te półgotowe wyroby, zwane wówczas 'patarafkami' kupowało się w galanteryjnych sklepach wraz z kolorowymi jedwabiami do haftu, które nazywały się poetycznie: filozele" (M. Samozwaniec, Maria i Magdalena, Szczecin 1987, s. 39-40).

10 „Fajans, odpowiednio wyrobiona masa wysokogatunkowej gliny z rozmaitymi domieszkami" (www.sjp.pwn.pl, [dostęp: 2.01.2017]).

11 W. Kopaliński, Przygody stów i przystów. Leksykon, Warszawa 2007, s. 136-139.

12 Inaczej dójka, kobieta ręcznie dojąca krowy - podaję za: tamże, s. 136.

${ }^{13}$ J. Bralczyk, Jeść, Olszanica 2014, s. 54.

${ }^{14}$ L. Drabik i in., Stownik języka polskiego, Warszawa 2011, s. 457.

15 S. Bąba, J. Liberek, Ze studiów nad frazeologia wspótczesnego języka polskiego, Poznań 2011, s. 93. 
Natomiast, słowo prywatka wyparte zostało ze współczesnej polszczyzny przez słowo domówka. Warto też zaznaczyć, że zmieniło się znaczenie słowa domówka, które w Stowniku języka polskiego pod redakcją W. Doroszewskiego zinterpretowane zostało jako „nauka domowa”16, a nie jak współcześnie się przyjmuje „impreza towarzyska zorganizowana w mieszkaniu”. Także słowo pasja funkcjonuje dziś w innym, niż dawniej, znaczeniu. „Pasja dziś to najczęściej tyle, co 'upodobanie', zamiłowanie. A właściwie: przedmiot tego zamiłowania. Kiedyś mówiono na to hobby albo bardziej po polsku: konik"17. Dawniej słowo pasja oznaczało namiętność, silne emocje. Takie jest też źródło powiedzenia: szewska pasja, czyli gwałtowna, niepohamowana złość, wściekłość, furia, utrata panowania nad sobą ${ }^{18}$.

Niezależnie od tych zmian, pewne doświadczenia społeczne zostały utrwalone i funkcjonują $\mathrm{w}$ języku, mimo że przedmioty, sytuacje do których się odnoszą dawno już uległy zapomnieniu. Do takich nośników treści kulturowych należą z całą pewnością związki frazeologiczne. Są to utrwalone zwyczajem połączenia dwóch lub więcej wyrazów. Ich znaczenie jest całościowe, przenośne i nie wynika ze znaczenia poszczególnych składników. Poszczególne wyrazy tworzące związek frazeologiczny mogą być w różnym stopniu ze sobą zespolone. Stanisław Skorupka wyodrębnił trzy typy związków ze względu na stopień zespolenia wyrazów:

- luźne - odznaczające się niewielkim stopniem scalenia wyrazów. W tym przypadku każdy składnik zachowuje swoje odrębne znaczenie;

- łączliwe - ich stopień zespolenia wyrazów jest znaczny, jednak każdy element zachowuje swoje znaczenie;

- stałe - charakteryzują się znacznym stopniem zespolenia, a znaczenie całości nie stanowi sumy znaczeń poszczególnych komponentów ${ }^{19}$. Wyrazów wchodzących w ich skład nie można zastąpić innymi wyrazami, gdyż związek frazeologiczny traci wówczas sens.

A.M. Lewicki z kolei wskazał na cztery zasadnicze elementy decydujące o tym, czy jednostkę leksykalną można uznać za związek frazeologiczny. Należą do nich:

- nieciągłość składu - związek frazeologiczny jest jednostką leksykalną nieciągłą, złożoną z przynajmniej dwóch wyrazów;

\footnotetext{
${ }^{16}$ www.sjp.pwn.pl., [dostęp: 2.01.2017].

17 J. Bralczyk w: J. Bralczyk, A. Markowski, J. Miodek, Trzy po 33, s. 120.

18 D. Podlawska, M. Świątek-Brzezińska, Stownik frazeologiczny języka polskiego, Warszawa - Bielsko Biała 2011, s. 252.

19 Tamże, s. 7.
} 
- stałość formy - frazeologizm ma stałą formę, a możliwość dokonywania zmian w obrębie związku jest niewielka i ściśle określona; ogranicza się zasadniczo do wymiany form gramatycznych lub leksykalnych (warianty frazeologiczne);

- globalność znaczenia - suma znaczeń składników nie równa się znaczeniu całości;

- utrwalenie w systemie języka - cechą frazeologizmu jest jego odtwarzanie $w$ tekstach na tej samej zasadzie, jak odtwarza się pojedynczy wyraz ${ }^{20}$.

Wspomniany autor zaproponował podział frazeologizmów ze względu na ich funkcję w zdaniu i wyodrębnił:

- frazy - mają budowę zbliżoną do zdania lub równoważnika zdań i pełnią funkcję wypowiedzenia. Ze względu na ich kompletność gramatyczną nie wymagają żadnego uzupełnienia w postaci dodatkowego słowa, $\mathrm{np}$. wyszło szydło z worka, głowa do góry, świat się przewrócit do góry nogami;

- zwroty - frazeologizmy pełniące funkcję czasowników; aby utworzyć zdanie należy uzupełnić zwrot elementem nominalnym wskazującym podmiot, którego ten stan dotyczy, np. kogoś krew zalewa, komuś spadt kamień $z$ serca, ktoś dolewa oliwy do ognia. Podstawową formą zwrotu jest połączenie czasownika z grupą nominalną (grupami nominalnymi) bezprzyimkową lub $\mathrm{w}$ formie wyrażenia przyimkowego ${ }^{21}$;

- wyrażenia rzeczownikowe, czyli związki frazeologiczne pełniące funkcję rzeczowników - przybierają postać grup lub szeregów rzeczowników, np. łabędzi śpiew, matżeństwo z rozsądku, na łonie rodziny22.

Przegląd literatury pozwala dostrzec jeszcze jedną grupę interpretacji dotyczących połączeń wyrazowych, wyodrębniającą jako osobną kategorię tzw. metafory potoczne (przysłowia), które w odróżnieniu od metafor literackich są wielokrotnie powtarzanymi zestawieniami słownymi (związkami frazeologicznymi), a ich znaczenie jest powszechnie rozumiane przez użytkowników języka. Przyjmują formę krótkiego, treściwego zdania anonimowego, które wyraża spostrzeżenia obyczajowe, psychologiczne, myśl ogólną, często w formie przenośnej23.

${ }^{20}$ Za: tamże, s. 7-8.

${ }^{21}$ A.M. Lewicki, Wprowadzenie do frazeologii syntaktycznej. Teoria zwrotu frazeologicznego, Katowice 1976, s. 46.

22 Tamże; D. Podlawska, M. Świątek-Brzezińska, Stownik frazeologiczny języka polskiego, s. 9.

23 S. Sierotwiński, Stownik terminów literackich, Wrocław - Warszawa - Kraków - Łódź Gdańsk 1986, s. 201. 
T. Milewski zwraca uwagę, iż związki frazeologiczne powstają w wyniku

stabilizacji starych wyrazów w nowej wartości znaczeniowej (...). Podobnie następuje niekiedy w języku stabilizacja jakiegoś nowego znaczenia całych grup wyrazowych użytych przenośnie w tekście ${ }^{24}$.

Związek frazeologiczny funkcjonuje zazwyczaj w świadomości użytkowników jako jedno pojęcie złożone z kilku słów (leksemów) i ma, jak podkreśla J. Tokarski, „charakter konwencjonalny i zastosowanie ograniczone"25. Przykładem takiego związku jest określenie ptasie mleczko, które odnosi się do bardzo konkretnego rodzaju słodyczy, a jego znaczenie wyrażone wprost jako zestawienie słów ptasie i mleczko nie odzwierciedla istoty jego pośredniego znaczenia jako całości. Frazeologizmy mogą też pełnić swoistą funkcję $\mathrm{w}$ wypowiedzi, funkcjonując równorzędnie $\mathrm{z}$ określeniami neutralnymi, jako te niosące treści zdecydowanie bardziej ekspresywne, np. erudyta i chodząca encyklopedia, a więc mają służyć przekazaniu pewnej treści, $\mathrm{np}$. w formie żartobliwej czy ironicznej. Inaczej interpretujemy określenie być $w$ dezabilu i być niekompletnie ubranym. To pierwsze oddaje "wygląd fizyczny kogoś nie do końca ubranego i jego zawstydzenie tą sytuacją. Zapożyczona w języka francuskiego forma "dezabil” ma jakby maskować rzeczywisty stan osoby, która nie zdążyła się ubrać lub właśnie zaczęła się ubierać26. Określenie być niekompletnie ubranym odbieramy jako bardziej neutralne. Trudno zatem nie zgodzić się z opinią D. Buttler, która wskazuje, iż frazeologizmy "sprzyjają subtelnemu wycieniowaniu emocjonalnemu tekstu, stanowią podstawę różnych zabiegów stylizacyjnych, przede wszystkim służą przekazaniu intencji żartobliwych mówiącego"27. Frazeologię potoczną (w odróżnieniu do frazeologii literackiej) cechuje ponadto obrazowość i odwołanie się do życia codziennego, rubaszność, a czasem wręcz dosadność i trywialność ${ }^{28}$. A.N. Baranov podkreśla natomiast, że forma wewnętrzna wielu frazeologizmów opiera się na schemacie kognitywnym,

24 T. Milewski, Jezykoznawstwo, Warszawa 1967, s. 82-83.

${ }_{25}$ J. Tokarski, Frazeologia i paremiologia, [w:] Dydaktyka nauki o języku. Wybór prac, red. J. Podracki, Warszawa 1986, s. 202.

${ }^{26}$ K. Kłosińska w: M. Budzińska (red.), Zapomniane stowa, Wołowiec 2014, s. 50.

27 D. Buttler, Zagadnienie poprawności leksykalno-semantycznej, [w:] Kultura języka polskiego. Zagadnienia poprawności leksykalnej (stownictwo rodzime), red. D. Buttler, H. Kurkowska, H. Satkiewicz, Warszawa 1982, s. 212.

28 Tamże. 
który nie ma nic wspólnego z ich znaczeniem aktualnym ${ }^{29} \mathrm{i}$ w tym aspekcie można dostrzec trudność związaną $\mathrm{z}$ ich stosowaniem $\mathrm{w}$ różnych sytuacjach komunikacyjnych, gdyż „są otwarte na cały szereg interpretacji semantycznych"30.

W związkach frazeologicznych utrwalone zostało to co ważne i cenne dla społeczeństwa $w$ każdym okresie jego historycznego rozwoju. Jest w nich ukryty sposób widzenia świata minionych pokoleń, relacje między ludźmi, preferowane wartości itp. Analiza utrwalonych w języku powiedzeń pozwala dostrzec i prześledzić, jak zmieniało się życie, co w poszczególnych etapach rozwoju społeczeństwa było istotne: uprawa roli, hodowla zwierząt, walka o autonomię i niezależność wspólnoty (państwa), handel i wymiana dóbr z sąsiadami (sąsiednimi miastami, państwami i in.), rozwój i rozbudowa miast itp. Różne są też źródła połączeń frazeologicznych. W literaturze wskazuje się następujące źródła związków frazeologicznych: mitologia, Biblia, historia, literatura, dawne obyczaje, wojskowość, obserwacja zachowań ludzi i zwierząt, rolnictwo, rzemiosło, dawny wymiar sprawiedliwości, obserwacja otaczającej rzeczywistości, kulinaria, gwara miejska $^{31}$. W dalszych rozważaniach wskażę wybrane $\mathrm{z}$ nich i zilustruję je przykładami.

Znaczna liczba frazeologizmów obecnych $w$ wielu językach europejskich, także w języku polskim, ma swoje źródło w mitologii greckiej i rzymskiej. Do takich powiedzeń można zaliczyć np. syzyfowa pracę, czyli pracę nie przynoszącą efektów, w objęciach Morfeusza - śpiąc, śniąc, być we śnie, węzet gordyjski - trudny do rozwiązania problem, skomplikowane zagadnienie, wzrok meduzy - nieprzyjemne, przenikliwe, paraliżujące spojrzenie, herkulesowa prace - pracę, której wykonanie przekracza ludzkie siły, homerycki śmiech - niepohamowany, donośny śmiech, ikarowe loty - śmiałe, ryzykowne przedsięwzięcia, które mogą zakończyć się nieszczęściem ${ }^{32}$. Cechą tej grupy frazeologizmów jest ich występowanie $\mathrm{w}$ podobnym znaczeniu $\mathrm{w}$ różnych językach i można je stosunkowo łatwo przełożyć na inne języki. Na przykład, powiedzenie ikarowe loty ma swój odpowiednik w języku angielskim icarian flight, francuskim - jeux icariens, w języku niemieckim - ikarische Spiele. Także inne, wybrane dla przykładu powiedzenie: koń trojański ma swój

${ }^{29}$ Za: A. Kiklewicz, Zrozumieć język. Szkice z filozofii języka, semantyki, lingwistyki komunikacyjnej, Łask 2007, s. 235.

30 Tamże.

${ }^{31}$ I. Płóciennik, D. Podlawska, Stownik wiedzy o jezyku, Warszawa - Bielsko Biała 2008, s. $81-83$.

${ }_{32}$ M. Czeszewski, K. Foremniak, Ludzie i miejsca w języku. Stownik frazeologizmów eponimicznych, Warszawa 2011. 
odpowiednik $\mathrm{w}$ języku angielskim - Trojan horse, francuskim - cheval de Troie, niemieckim - Trojanisches Pferd, włoskim - cavallo di Troia. Takim uniwersalnym związkiem frazeologicznym jest też puszka Pandory, czyli sprawa, której poruszenie lub przedsięwzięcie wywołało wiele nieoczekiwanych, przykrych skutków, kłopotów, nieszczęść. Odpowiednikiem francuskim tego powiedzenia jest - boite de Pandore, niemieckim - Buchse der Pandora, włoskim - vaso di Pandora. Podobnie rzecz wygląda w przypadku powiedzeń mających swoje źródło biblijne. Do tej grupy można zaliczyć chociażby taki związek frazeologiczny, jak: miłosierny samarytanin, który określa człowieka miłosiernego, litościwego, dobrego, spieszącego z pomocą chorym. Występuje także w innych językach: angielskim - Good Samaritian, francuskim - Bon Samaritian, niemieckim - barmherziger Samariter, włoskim - buon samaritano. Podobnie $\mathrm{w}$ różnych językach funkcjonuje określenie niewierny Tomasz, które oznacza człowieka wątpiącego, niedowiarka, sceptyka. Francuskim odpowiednikiem tego powiedzenia jest: un saint Thomas, niemieckim - unglabiger Thomas, włoskim - essera come san Tomasso lub fare come san Tomasso 33 .

Duża grupa związków frazeologicznych odzwierciedla antropocentryczny punkt widzenia świata. Dowodzą tego liczne powiedzenia odnoszące się do części ciała ludzkiego, np. od stóp do głów, mieć coś na końcu języka, mieć głowe na karku, zawrócić komuś w głowie, mieć oczy dookoła głowy, pójść za głosem serca, coś jest w dobrych rękach, mieć nóż na gardle, stanać komuś ościa $w$ gardle, nie puszczać pary z gęby, robić $z$ gęby cholewę itp. Warto w tym miejscu, dla przykładu, przytoczyć interpretację Jerzego Bralczyka powiedzenia nabrać wody w usta, który w sposób następujący wyjaśnia jego znaczenie:

nie ma fizycznej możliwości mówienia z wodą w ustach. Nie każde mówienie jest milczeniem, milczenie jest wtedy, gdy spodziewane jest mówienie. Milczący pokazuje, że milczy. Zdarza mu się nawet o tym mówić, żeby jego milczenie zauważono wtedy stosuje figurę retoryczną zwaną praeteritio lub popada w sprzeczność. Nabieranie wody w usta jest dobrym sposobem manifestowania milczenia, ale jest kłopotliwe w stosowaniu ${ }^{34}$.

Interesującą grupą są też powiedzenia odnoszące się do kolorów. W języku polskim funkcjonują np. takie pojęcia, jak: nie mieć o czymś zielonego pojęcia, czyli nie znać się na czymś, nie orientować się, nic o czymś nie wiedzieć 35 . Innym powiedzeniem z tej grupy jest czarna owca, czyli ktoś kom-

33 Tamże, s. 182-183.

34 E. Sobol, Stownik frazeologiczny z Bralczykiem, Warszawa 2008, s. 234.

${ }^{35}$ S. Bąba, J. Liberek, Mały stownik frazeologiczny wspótczesnego języka polskiego, Warszawa 2003, s. 400. 
promitujący własne środowisko, wyrzutek, odszczepieniec, a także biały kruk - rzadka książka, niezwykle cenny egzemplarz, myśleć o niebieskich migdałach - nie móc skupić uwagi na niczym, myśleć o błahostkach. W języku polskim, podobnie jak $w$ innych językach tzw. kultury zachodniej, popularne są też związki frazeologiczne odnoszące się do świata zwierząt. Przykładem może być powiedzenie "kupować kota w worku” - kupować coś bez sprawdzenia tego, co się rzeczywiście kupuje. Powiedzenie to prawdopodobnie sięga czasów średniowiecza, kiedy produkty kupowało się w workach. W. Kopaliński opisując jego etymologię wskazuje, że "przedmiot handlu wydaje się dość dziwny, tym dziwniejszy, im przysłowie starsze, bo przecież nikt normalny na targu kotów nie kupował" 36 . W worku można było kupić prosię, czy zająca i pierwotnie to powiedzenie dotyczyło prosięcia lub zająca. Warto podkreślić, że w Polsce w języku łowieckim zająca nazywano właśnie kotem. Powiedzenie wskazuje, że $\mathrm{w}$ pośpiechu, przy braku należytej uwagi można kupić takiego zepsutego, nieświeżego zająca ${ }^{37}$. Innym interesującym powiedzeniem jest: "ganiać jak kot z pęcherzem” („latać jak kot z pęcherzem”), czyli ruszać się nerwowo, przemieszczać się z miejsca na miejsce w sposób gwałtowny. K. Głowińska w Słowniku frazeologicznym wskazując historię powstania tego związku frazeologicznego, informuje, iż w przeszłości popularna była zabawa, która polegała na tym, że kotu do ogona przywiązywano wysuszony rybi pęcherz. Jego wnętrze wypełniano grochem, który wydawał dźwięki przy każdym ruchu zwierzęcia. W panice próbowało ono uciec przed przedmiotem, który wydawał przerażające dla niego dźwięki ${ }^{38}$. Nie mogło jednak tego zrobić, a im bardziej próbowało uciec, tym dźwięk, który wydawał pęcherz, był głośniejszy i bardziej dokuczliwy. Z kolei, do powiedzenia "kot zawsze spada na cztery łapy" w interesujący sposób odnosi się J. Bralczyk pisząc, iż „ci, co tu (w powiedzeniu) przyrównani są do trudno uszkadzanych czy uszkadzających się kotów, cieszyć się mogą naszym względnym podziwem, ale nie bezwzględną sympatią: z każdej opresji wyjdą cało, a nawet, choć o tym się już nie mówi, z jakimiś korzyściami"39. Nie tylko kot jest bohaterem związków frazeologicznych, pies jest bohaterem ponad pięćdziesięciu związków frazeologicznych występujących w języku polskim, np. czuć się jak zbity pies, coś jest jak psu z gardła wyjęte, wieszać na kimś psy, być wiernym, jak pies"0, wilk - o wilku mowa, patrzeć na kogoś wilkiem,

${ }^{36}$ W. Kopaliński, Koty w worku, czyli z dziejów pojęć i rzeczy, Warszawa 2006, s. 10.

${ }^{37}$ K. Głowińska, Stownik frazeologiczny, Suchy Las 2008, s. 175.

38 Tamże.

39 J. Bralczyk, Porzekadła na każdy dzień, Warszawa 2009, s. 113.

40 Szerzej na temat zwierząt w związkach frazeologicznych w: K. Kuszak, Świat zwierząt w związkach frazeologicznych $i$ w literaturze dziecięcej, Wychowanie na co Dzień, 2015, 1, s. I-VIII. 
wilczy apetyt, osioł - uparty jak osioł. Bohaterami związków frazeologicznych są też wymyślone przez człowieka i utrwalone w podaniach oraz legendach zwierzęta, np. bazyliszek - symbolizujący zło, grzech, diabła, złego człowieka, strażnika skarbu ${ }^{41}$ i powiedzenie wzrok (spojrzenie) bazyliszka - zabójcze, przenikające, złowieszcze, nieżyczliwe, nienawistne spojrzenie.

Znacząca jest też grupa frazeologizmów nawiązujących do świata roślin. A. Nowakowska zauważa, iż

w czasach przedindustrialnych, gdy powstała większość używanych dzisiaj jednostek frazeologicznych, kontakt $\mathrm{z}$ naturą był o wiele ściślejszy. Nic więc bardziej zrozumiałego, niż nawiązywanie przez użytkowników języka w porównaniach do drzew, krzewów, owoców i innych obiektów roślinnych² ${ }^{42}$

Wskazuje ona, że w Słowniku frazeologicznym wspótczesnej polszczyzny aż 45 popularnych frazeologizmów zawiera jako komponent nazwę roślinną. Pochodzą one z różnych okresów rozwoju języka, a najwcześniejsze poświadczone frazeologizmy, jak rzucać grochem o ściane, nie owijać w bawetne, powstały w XVI-XVII wieku. Rośliny symbolizują też ludzkie cechy, jak np. chtop jak dąb, trzaść się jak osika, chwiać się jak trzcina na wietrze, wiedzieć, co $w$ trawie piszczy itp. Rośliny wykorzystywano podczas rytuałów i obrzędów, co zachowało się w języku np. w postaci powiedzenia siać rutę. Stefan Kłosiewicz i Olga Kłosiewicz na temat tej rośliny piszą następująco:

ruta związana była nieodłącznie z obyczajami weselnymi. Miała symbolizować niewinność i nadzieję. Panny młode zdobiły nią głowy, a drużbowie czapki. Ruciany wianek stał się wręcz symbolem panny do wzięcia. O tych, które ominęło szczęście bycia mężatką mówiono, że rutkę sieją, by zawsze trwać w gotowości do przywdziania wianka ${ }^{43}$.

Funkcjonujące w języku polskim frazeologizmy dowodzą też skłonności naszych przodów do „wojaczki”, np. kruszyć kopie, spalić za sobq mosty, stanać $w$ szrank $i^{4}$, ale też „opisują" rycerskie obyczaje, militaria i tradycję wojskową, np. na placu boju, grubszy kaliber, otoczyć się pancerzem ochronnym, podnieść larum, uderzyć rykoszetem, wysadzić kogoś z siodła45. Interesującą etymologię związku iść jak w dym (pójść jak w dym, uderzyć do kogoś jak w dym) proponuje K. Handke. Współczesne znaczenie tego frazeologizmu oznacza „udać się do kogoś z prośbą, która na pewno zostanie spełniona, inaczej iść bez waha-

\footnotetext{
${ }^{41}$ W. Kopaliński, Stownik symboli, Warszawa 2012, s. 12.

42 A. Nowakowska, Świat roślin w polskiej frazeologii, Wrocław 2005, s. 59.

43 S. Kłosiewicz, O. Kłosiewicz, Przyroda w polskiej tradycji, Warszawa 2011, s. 193.

${ }^{44}$ S. Bąba, J. Liberek, Ze studiów nad frazeologia, s. 10-11.

${ }^{45}$ D. Podlawska, M. Świątek-Brzezińska, Stownik frazeologiczny języka polskiego, s. 469-470.
} 
nia, śmiało, pewnie, prosto". Zaś jego źródłosłów sięga XVI-XVII wieku, gdy upowszechniła się broń palna. $\mathrm{W}$ tamtych czasach wymagało to długiego ładowania. Tak więc, jak pisze autorka, w starciu bojowym po oddanej salwie piechoty powstawał obłok dymu, który tworzył zasłonę umożliwiającą kawalerii przeciwnika natarcie. Było ono bezpieczne do momentu, gdy piechota po załadowaniu broni, mogła wystrzelić46. Także przysłowie przed bitwa nie trąb wygranej, znane już w XVII wieku, sugerujące, iż nie należy uznawać za sukces czegoś, co jeszcze nie zostało zakończone, ma swoje źródło $\mathrm{w}$ tradycji wojskowej. Z kolei, kultura dworska utrwalona została $\mathrm{w}$ takich powiedzeniach, jak np. dworskie maniery, rycerskie zachowanie.

Niemała grupa określeń związana jest z przedmiotami popularnymi przed wieloma laty, które dzisiaj już nie występują. Pozostały po nich jednak powiedzenia. Takim przykładem może być określenie nie w kij dmuchat, używane na podkreślenie dużej wartości czegoś. Nawiązuje ono do dawnego polskiego zwyczaju szlacheckiego, który polegał na wypiciu zawartości kielicha bez podstawki (zwanego kijem lub kulawką), bez zaczerpnięcia oddechu (dmuchania). Ten niemałych rozmiarów kielich wypełniony był winem. Kto nie potrafił wypić wina bez zaczerpnięcia powietrza, ochlapywał się trunkiem. Dodatkowo, takiemu nieporadnemu szlachcicowi wlewano za kołnierz kielich wody ${ }^{47}$. Do dawnych tradycji nawiązuje też inne powiedzenie czytać od deski do deski. W tamtych czasach książki oprawiano w drewniane obwoluty. $\mathrm{Z}$ tego powiedzenia wynika, że kto czytał dokładnie, ten czytał od deski do deski. Współcześnie zastępujemy to powiedzenie innym: czytać od pierwszej do ostatniej karty48. Innym popularnym powiedzeniem związanym z książkami jest określenie mól książkowy. Mól książkowy jest owadem żerującym w starych książkach, żywi się zgromadzonym między kartkami kurzem lub grzybami pokrywającymi karty starych ksiąg, które rozwijają się w wilgotnym papierze. Mnożąc się w sprzyjających warunkach, niszczy jednocześnie papier, oprawę książki, powoduje nieodwracalną utratę cennych zapisków. Znaczenie przenośne tego powiedzenia, popularne we współczesnym języku polskim, odnosi się do osoby lubiącej czytać i czytającej dużo książek, "pochłania książki” jak wspomniany owad. Jak podają S. Bąba i J. Liberek, mól książkowy, to „człowiek zagrzebany w książkach, ślęczący nad nimi, nie widzący świata poza nimi ${ }^{49}$.

${ }^{46}$ K. Handke, O jezzyku dobrze i źle, Warszawa 2004, s. 294-295.

${ }^{47}$ Za: K. Głowińska, Stownik frazeologiczny, s. 153.

48 Szerzej na ten temat w: K. Kuszak "Opowiadać bajki" $i$ "czytać od deski do deski” - doświadczenie kulturowe zapisane w jezyku, [w:] Kultura - sztuka - edukacja, t. II, red. B. Kurowska, K. Łapot-Dzierwa, Kraków 2016.

${ }^{49}$ S. Bąba, J. Liberek, Maty stownik frazeologiczny, s. 146. 
We współczesnym języku funkcjonują takie powiedzenia, których źródło jest zazwyczaj nieznane użytkownikom. Przykładem może być związek frazeologiczny tajemnica poliszynela. Jak podaje Stownik języka polskiego, poliszynel to „postać komiczna z ludowej komedii włoskiej, wprowadzona później na scenę francuską i do teatru kukiełek"50, zaś tajemnica poliszynela to rzekoma tajemnica, znana wszystkim od dawna ${ }^{51}$. Zdaniem Katarzyny Kłosińskiej, Poliszynel był bohaterem XIX-wiecznej powiastki Octave’a Fauilleta, zatytułowanej „Życie Poliszynela i jego liczne przygody". Jak podaje autorka, w jednym z rozdziałów opisana jest historia, jak cwany Poliszynel chciał się zemścić na niewinnym panu de Bugolinie za to, że ten naśmiewał się $\mathrm{z}$ niego przed królem. Jego zemsta polegała na tym, że posmarował podeszwy butów de Bugolina smołą, by podczas zbliżającego się balu nie mógł oderwać nóg od podłogi. Poliszynel rozsiewał plotkę, że przyczyną dziwnego zachowania tancerza są jego ułomności, informując zarówno króla, jak i dworzan. Wkrótce wszyscy poznali tajemnicę, ale każdy udawał, że nic o niej nie wie. Stąd tajemnica poliszynela to nic innego, jak źle strzeżona tajemnica ${ }^{52}$. Podobnie rzecz ma się z określeniem zbić kogoś z pantałyku. Krystyna Długosz-Kurczbowa zauważa, że samo słowo pantałyk ma niepewną etymologię i jest niejednoznaczne. Językoznawcy wymieniają trzy możliwe źródła tego słowa: azerbejdżańskie słowo pand oznaczające chytrość, ale też wiedzę, ukraińskie pantalik - pętla, bawarskie pantl - pętla, problem do rozwiązania. Słowo pantatyk występuje tylko w wymienionym przeze mnie powiedzeniu i oznacza wprawić kogoś w zakłopotanie, pozbawić go pewności siebie, zbić z tropu ${ }^{53}$. Katarzyna Kłosińska wskazuje, że pierwotną formą słowa pantatyk był pantołęk i oznaczało kij, który jest używany w grach sportowych typu palant. „Mówiono, że ktoś zbił kogoś z pantołęku, jeśli podbił jego piłkę. Straciwszy w ten sposób piłkę gracz był zdezorientowany, tracił pewność siebie"54. Według wspomnianej autorki istnieje też inna wersja dotycząca źródeł tego powiedzenia. Pantałykiem miało być, według niej, podwyższenie, na którym stał zawodnik grający w kule. Jego zadaniem było zbić kule przeciwnika. "Zdarzało się jednak, że zamiast w kulę trafiano w samego gracza - zbijano go z pantałyku, przez co tracił rezon".

\footnotetext{
${ }^{50}$ L. Drabik i in., Stownik jezzyka polskiego, s. 693.

51 S. Bąba, J. Liberek, Maty stownik frazeologiczny, s. 248.

52 K. Kłosińska, Co w mowie piszczy? Poznań 2013, s. 35-36.

${ }^{53}$ www.sjp.pwn.pl. [dostęp: 2.01.2017].

${ }^{54}$ K. Kłosińska, Co w mowie piszczy? s. 24.
} 


\section{Podsumowanie}

Językoznawca Andrzej Markowski zauważył, że „język jest skarbnicą wiedzy o przeszłości narodu i tezaurusem kultury narodowej, a także spoiwem narodu, istotnym składnikiem jego tożsamości"55. Niewątpliwie jest więc dla każdego społeczeństwa wartością. Przytoczone w niniejszym opracowaniu przykłady związków frazeologicznych odzwierciedlają bogactwo i różnorodność doświadczeń kulturowych zapisanych w naszym języku. Dowodzą, iż „słowa jednocześnie etykietują rzeczywistość, dostarczając nazw dla tego, co swój byt wiedzie niezależnie od nich" jak też "stwarzają świat, wpływając na sposób, w jakim go postrzegamy"56, pozwalając na subtelne wycieniowanie znaczeń, które chcemy za pomocą języka wyrazić. Użytkownicy języka korzystają z bogactwa w nim utrwalonego, nie zawsze uświadamiając sobie, że mają do dyspozycji niezwykle cenny spadek po minionych pokoleniach, który wymaga uwagi i troski. Trzeba jednak podkreślić, że język rozwija się, zmienia. Mamy wiele przykładów ilustrujących to, jak utrwalone $\mathrm{w}$ świadomości związki frazeologiczne zyskują nowe znaczenia dzięki współczesnym mediom, reklamie. Konsumpcyjny styl życia kreowany przez reklamę zmienia doświadczenia kulturowe współczesnych pokoleń. Oddziałuje też na język, do którego przenikają takie określenia, jak I'm lovin' it - McDonald's, The freshmaker - Mentos, No to Frugo. Jerzy Bralczyk analizując ostatnie wymienione powiedzenie pisze następująco:

Frugo, bo ma się kojarzyć z owocami, a każdy odniesie początek nazwy („fru”) do owoców: „frukta”, "friut” itp. Ale jednocześnie "fru!” to onomatopeja fruwania. Jak ktoś, czy coś frunie, to robi fru! Albo fruuu! (...) No to Frugo-znakomicie, agresywnie skonstruowane hasło miało [i ma w dalszym ciągu - dop. K.K.] ogromny potencjał pobudzający i integrujący. "No to cyk!” - wołali i wołają do dziś ci, co chcą się napić. "No to już!". Zapowiedź „no to" i kadencyjne „już”. Albo „fru go”. Mamy wrażenie, że naturalnie reagujemy na to, na co trzeba naturalnie reagować57.

Język zmienia się i wzbogaca, wymaga też dbałości o jego rozwój i świadomego korzystania $\mathrm{z}$ bogactwa $\mathrm{w}$ nim zawartego. To bogactwo ukryte jest $w$ tradycyjnych i nowych związkach frazeologicznych. Warto je zatem odkrywać jak najwcześniej z dziećmi i młodzieżą, wspólnie interpretować, poszukiwać ich znaczeń i źródeł. Takie działania, które nazywam „kąpielą

55 A. Markowski, Kultura jezzyka polskiego. Teoria. Zagadnienia leksykalne, Warszawa 2005, s. 12.

${ }^{56}$ M. Bańko, Stowo wstępne, [w:] J. Bralczyk, Świat przez słowa, Warszawa 2009, s. 5.

${ }^{57}$ J. Bralczyk, 500 zdań polskich, Warszawa 2015, s. 312. 
frazeologiczną"58, stymulują wrażliwość na język i rozwijają świadomość językową współczesnych użytkowników języka polskiego. Inspirują do twórczego, kreatywnego używania słów, wzbogacania ich indywidualnego zasobu przez każdą jednostkę. W edukacji polonistycznej warto zadbać, by młode pokolenie wiedziało i rozumiało, jak zmienia się język, jakie są źródła i mechanizmy tych zmian, $\mathrm{w}$ jaki sposób w języku utrwalone zostały doświadczenia społeczne minionych pokoleń i jak $\mathrm{z}$ tego zasobu możemy współcześnie korzystać. Bo przecież, jak pisał Wilhelm von Humboldt:

człowiek wprawdzie wykracza poza swój język; stanowi sobą więcej, niż potrafi wypowiedzieć w słowach; musi jednak schwytać w słowa ulotnego ducha, by go zatrzymać, a słów używać jako oparcia, ażeby sięgać poza nie coraz dalej59.

W języku, w jego zasobie należy więc szukać oparcia dla kształtowania tożsamości jednostki, społeczności, narodu.

\section{BIBLIOGRAFIA}

Anusiewicz J., Dąbrowska A., Fleischer M., Językowy obraz świata i kultura. Projekt koncepcji badawczej, [w:] Jezyk a kultura, t. 13, Wydawnictwo Uniwersytetu Wrocławskiego, Wrocław 2000.

Bańko M., Stowo wstępne, [w:] J. Bralczyk, Świat przez słowa, PWN, Warszawa 2009.

Baylon Ch., Mignot X., Komunikacja, Wydawnictwo Flair, Kraków 2008.

Bąba S., Liberek J., Mały słownik frazeologiczny wspótczesnego języka polskiego, Oficyna Wydawnicza Rytm, Warszawa 2003.

Bąba S., Liberek J., Ze studiów nad frazeologia wspótczesnego języka polskiego, Wydawnictwo Poznańskie, Poznań 2011.

Bralczyk J., Porzekadta na każdy dzień, PWN, Warszawa 2009.

Bralczyk J., Jeść, Wydawnictwo BOSZ, Olszanica 2014.

Bralczyk J., 500 zdań polskich, Wydawnictwo Agora, Warszawa 2015.

Bralczyk J., Markowski J., Miodek J., Trzy po 33, Wydawnictwo Agora, Warszawa 2016.

Budzińska M. (red), Zapomniane stowa, Wydawnictwo Czarne, Wołowiec 2014.

Buttler D., Zagadnienie poprawności leksykalno-semantycznej, [w:] Kultura języka polskiego. Zagadnienia poprawności leksykalnej (stownictwo rodzime), red. D. Buttler, H. Kurkowska, H. Satkiewicz, PWN, Warszawa 1982.

Czeszewski M., Foremniak K., Ludzie i miejsca w języku. Stownik frazeologizmów eponimicznych, Wydawnictwo Uniwersytetu Warszawskiego, Warszawa 2011.

Drabik L., Kubiak-Sokół E., Sobol E., Wiśniakowska L., Stownik języka polskiego, Wydawnictwo Naukowe PWN, Warszawa 2011.

${ }^{58}$ K. Kuszak, Świat związków frazeologicznych w jezzyku dziecka. Inspiracje teoretyczne - badania - implikacje praktyczne, Poznań 2014, s. 138 i n.

${ }^{59}$ W. von Humboldt, O myśli i mowie, Warszawa 2011, s. 165. 
Filipiak M., Obszar badawczy socjologii kultury, [w:] Wprowadzenie do socjologii kultury, red. M. Filipiak, Wydawnictwo UMCS, Lublin 2009.

Fleischer M., Obraz świata. Ujęcie z punktu widzenia teorii systemów i konstruktywizmu, Acta Universites Wratislaviensis, t. 13, Wrocław 2000.

Głowińska K., Słownik frazeologiczny, Twoje Książki, Suchy Las 2008.

Golka M., Socjologia kultury, Wydawnictwo Naukowe Scholar, Warszawa 2007.

Handke K., O języku dobrze i źle, Slawistyczny Ośrodek Wydawniczy, Warszawa 2004.

Kiklewicz A., Zrozumieć język. Szkice z filozofii języka, semantyki, lingwistyki komunikacyjnej, Oficyna Wydawnicza Leksem, Łask 2007.

Kłosiewicz S., Kłosiewicz O., Przyroda w polskiej tradycji, Sport i Turystyka Muza SA, Warszawa 2011.

Kłosińska K., Co w mowie piszczy? Wydawnictwo Publicat, Poznań 2013.

Kłoskowska A., Socjologia kultury, PWN, Warszawa 2007.

Kopaliński W., Koty w worku, czyli z dziejów pojęć i rzeczy, Oficyna Wydawnicza Rytm, Warszawa 2006.

Kopaliński W., Przygody słów i przysłów. Leksykon, Oficyna Wydawnicza Rytm, Warszawa 2007.

Kopaliński W., Stownik symboli, Oficyna Wydawnicza Rytm, Warszawa 2012.

Kurcz I., Psychologia jezyka i komunikacji, Wydawnictwo Naukowe Scholar, Warszawa 2005.

Kuszak K., Świat związków frazeologicznych w języku dziecka. Inspiracje teoretyczne - badania implikacje praktyczne, Wydawnictwo Naukowe UAM, Poznań 2014.

Kuszak K., Świat zwierząt w związkach frazeologicznych $i$ w literaturze dziecięcej, Wychowanie na co Dzień, 2015, 1.

Kuszak K., "Opowiadać bajki” $i$ „czytać od deski do deski” - doświadczenie kulturowe zapisane $w$ języku, [w:] Kultura - sztuka - edukacja, t. II, red. B. Kurowska, K. Łapot-Dzierwa, Wydawnictwo Naukowe Uniwersytetu Pedagogicznego, Kraków 2016.

Lewicki A.M., Wprowadzenie do frazeologii syntaktycznej, Teoria zwrotu frazeologicznego, Wydawnictwo Uniwersytetu Śląskiego, Katowice 1976.

Markowski A., Kultura jezyka polskiego. Teoria. Zagadnienia leksykalne, PWN, Warszawa 2005.

Milewski T., Jezzykoznawstwo, PWN, Warszawa 1967.

Nowakowska A., Świat roślin w polskiej frazeologii, Wydawnictwo Uniwersytetu Wrocławskiego Wrocław 2005.

Płócennik D., Podlawska D., Słownik wiedzy o języku, Wydawnictwo Pedagogiczne PWN, Warszawa - Bielsko Biała 2008.

Podlawska D., Świątek-Brzezińska M., Stownik frazeologiczny języka polskiego, Wydawnictwo Szkolne PWN, Warszawa - Bielsko Biała 2011.

Samozwaniec M., Maria i Magdalena, Wydawnictwo "Glob”, Szczecin 1987.

Sapir E., Kultura a osobowość, Państwowy Instytut Wydawniczy, Warszawa 1978.

Sierotwiński S., Stownik terminów literackich, Ossolineum, Wrocław - Warszawa - Kraków - Łódź - Gdańsk 1986.

Skorupka S., Stownik frazeologiczny języka polskiego, Wiedza Powszechna, Warszawa 1977.

Sobol E., Stownik frazeologiczny z Bralczykiem, Wydawnictwo Naukowe PWN, Warszawa 2008.

Sztompka P., Socjologia. Analiza społeczeństwa, Społeczny Instytut Wydawniczy "Znak”, Kraków 2012. 
Tokarski J., Frazeologia i paremiologia, [w:] Dydaktyka nauki o języku. Wybór prac, red. J. Podracki, Wydawnictwa Uniwersytetu Warszawskiego, Warszawa 1986.

von Humboldt W., O myśli i mowie, Wydawnictwo Naukowe PWN, Warszawa 2011. www.sjp.pwn.pl., [dostęp: 2.01.2017]. 
